Abstracta Iranicacta Iranica

Revue bibliographique pour le domaine irano-aryen

Volume 32-33 | 2013

Comptes rendus des publications de 2009-2010

\title{
Tadashi Tanabe. Diffusion of the Greek gesture of touching another's chin with raised hand in the East
}

\section{Vito Messina}

\section{(2) OpenEdition}

12 Journals

\section{Electronic version}

URL: http://journals.openedition.org/abstractairanica/40582

DOI: 10.4000/abstractairanica.40582

ISSN: 1961-960X

Publisher:

CNRS (UMR 7528 Mondes iraniens et indiens), Éditions de l'IFRI

\section{Printed version}

Date of publication: 1 December 2013

ISSN: 0240-8910

\section{Electronic reference}

Vito Messina, «Tadashi Tanabe. Diffusion of the Greek gesture of touching another's chin with raised hand in the East », Abstracta Iranica [Online], Volume 32-33 | 2013, document 203, Online since 01 July 2016, connection on 04 October 2020. URL : http://journals.openedition.org/abstractairanica/40582 ; DOI : https://doi.org/10.4000/abstractairanica.40582

This text was automatically generated on 4 October 2020.

Tous droits réservés 


\title{
Tadashi Tanabe. Diffusion of the Greek gesture of touching another's chin with raised hand in the East
}

\author{
Vito Messina
}

\section{REFERENCES}

Tadashi Tanabe. « Diffusion of the Greek gesture of touching another's chin with raised hand in the East ». Parthica, 12, 2010, p. 81-94.

1 The gesture of touching or grasping another person's chin with one hand supposedly originated in Greece. It was widespread in the ancient Near and Far East during the Hellenistic period, and survived for a long time even though it apparently became sporadic. Several scholars have speculated on this gesture's meaning, which is still obscure. No exhaustive survey has been made of its diffusion in Asia. This article comments on several documents from ancient Persia and Gandhara that present this gesture in different contexts. It compares these sources iconographically with the Greek prototypes. The gesture might represent universal attitudes, such as coquetry or entreaty. It must have had different meanings depending on the artist's cultural background. 


\section{AUTHORS}

VITO MESSINA

Università di Torino 